\title{
ANALIZA POGREŠAKA LOVACA KOD PROCJENE UDALJENOSTI CILJA
}

\section{AN ERROR ANALYSIS OF HUNTERS IN ESTIMATING THE TARGET DISTANCE}

\author{
TOMLJANOVIĆ, K*., SELETKOVIĆ, A., MALNAR, M., GRUBEŠIĆ, M
}

\begin{abstract}
Sažetak / Abstract
U svakodnevnom lovnom gospodarenju pravilna procjena udaljenosti pojedine divljači, posebice vrsta krupne divljači, od odlučujućeg je značenja kod izvršavanja odstrela. Većina pušaka užljebljene cijevi koja se danas koristi za odstrel opremljena je optičkim nišanima koji se u pravilu upucavaju na $100-150 \mathrm{~m}$. Zavisno o kalibru, visini optičkog nišana, težini zrna metka, udaljenosti i kutu pod kojim se gađa, kao i još nekim manje važnim parametrima ovisi uspješnost samog odstrela, odnosno točnost pogotka. Često puta razlog promašaja kod pokušaja odstrela treba tražiti upravo u pogrešno procijenjenoj udaljnosti divljači koja se cilja. U radu je analiziran utjecaj različitih čimbenika na pogreške kod procjene udaljenosti cilja. Procjena udaljenosti objekata u prirodi istraživana je na uzorku od 40 lovaca različite životne dobi, lovačkog staža i obrazovanja. Istraživanje je provedeno u reljefno tri tipa staništa, nizinskom (do 200 m.n.v.), brdskom (200 - 800 m.n.v.) i gorskom dijelu (preko 800 m.n.v.). Kako bi se otklonila pristranost svaki lovac je testiran na deset različito udaljenih objekata. Kontrolna mjerenja izvršena su laserskim daljinomjerom. Dobiveni rezultati pokazuju kako je pogreška procjene udaljenosti samo donekle povezana s lovačkim iskustvom, te je u većoj mjeri ovisna o životnoj dobi. Najviše griješe najmlađi i najstariji lovci, dok je pogreška najmanja kod lovaca životne dobi 40 - 60 god. Gledano lovački staž najviše su griješili lovci sa lovačkim stažom 10 - 20 god. Analizom stupnja obrazovanja i pogrešaka procjene udaljenosti ustanovljeno je kako su najmanje pogreške zabilježene kod lovaca visokog obrazovanja. Svi lovci prosječno procjenjuju manju udaljenost od stvarno izmjerene. Porastom udaljenosti povećava se i pogreška procjenjene udaljenosti.
\end{abstract}

KLJUČNE RIJEČI: procjena udaljenosti, lovci, lovno gospodarenje, stanište

\section{UVOD}

\section{INTRODUCTION}

Dubinska percepcija je sposobnost da se vidi trodimenzionalni volumen i prostorni raspored objekata u odnosu jednog na drugi, kao i na samog gledatelja. Ta dubinska percepcija kod ljudi ostvaruje se pomoću različitih znakova u prirodi, gdje se oči odnosno mozak oslanja na određene zakonitosti pravilnosti u okolišu (Watson i Enss, 2012).
Znajući veličinu objekta iz prethodnog iskustva naš mozak može izračunati udaljenost na temelju veličine objekata na mrežnici (Abel 2014). Za pravilnu dubinsku percepciju potrebno je da oba oka sinhronizirano fokusiraju objekt koji se promatra. Na taj način, promatrajući isti objekt istovremeno iz dva različita kuta, u mozgu se stvara plastična slika objekta (Tran i sur., 2010) te se dobivaji svi ostali podaci o objektu promatranja (Greene i Oliva, 2009; Oliva i Schyns, 2000; Rousselet i sur., 2005; Sanocki, 2003). Na percepciju

\footnotetext{
* Dr. sc. Kristijan Tomljanović, e-mail: tomljanovic@sumfak.hr, Prof. dr. sc. Marijan Grubešić, email: grubesic@sumfak.hr., Sveučilište u Zagrebu, Šumarski fakultet, Zavod za zaštitu šuma i lovno gospodarenje, Svetošimunska 25, 10000 Zagreb, HRVATSKA

Izv. prof. dr. sc. Ante Seletković, e-mail: seletkovic@sumfak.hr, Sveučilište u Zagrebu, Šumarski fakultet, Zavod za lzmjeru i uređivanje šuma, Svetošimunska 25, 10000 Zagreb, HRVATSKA

Maja Malnar, e-mail: majamalnar1@gmail.com, Sveučilište u Zagrebu, Šumarski fakultet, Svetošimunska 25, 10000 Zagreb, HRVATSKA
} 
objekta promatranja velik utjecaj imaju različiti faktori poput oblika, svjetla, pozadine, kontrasta itd. koji su međusobno isprepleteni i od određenog većeg ili manjeg međusobnog utjecaja (Kogo i sur., 2014; Henderson i Hollingworth, 1999; Biederman i sur., 1982; Boyce i sur., 1989; Gegenfurtner i Rieger, 2000). Rezultati istraživanja Bell-a i sur.(1972) pokazuju da se dubinska percepcija u pravilu pogoršava u četvrtoj dekadi života. Također, utvrđeno je da u mlađoj životnoj dobi dubinska percepcija značajno ovisna je o inteligenciji ispitanika (Sinha i Shukla, 1974). Međutim postoji izvjesan broj studija koje zaključuju kako dubinska percepcija nije izravno povezana sa starošću (Hofstetter i Bertsch, 1976; Greene i Madden, 1987; Yekta i sur., 1989), dok neke studije govore kako pojedini segmenti dubinskog raspoznavanja i direrencijalnih promjena povezani s vremenom koje je potrebno za uočavanje promjena dajući prednost mlađim dobnim kategorijama naspram starijih (Norman i sur., 2000). S druge strane rezultati te studije pokazuju je da se kod starijih dobnih kategorija primijećuje smanjena sposobnost uočavanja 3D objekata $\mathrm{u}$ pokretu. Isti autor zaključuje kako se vjerojatno u svakodnevnom životu uslijed smanjene funkcionalnosti starije uzrasne kategorije ljudi sve više oslanjaju na druge izvore informacija o stanju, kao što su unutarnja konture, sjenčanje, okluzija granice i nejednakost. Iz navedenog vidljivo je da je znanost još uvijek neodlučna, nisu dati još svi odgovori, a istraživanja u tom smjeru su i dalje aktualna.

U praktičnom dijelu lovnog gospodarenja, dubinska percepcija važna je kod procjene brzine kretanja nekog objekta, kao i kod procjene udaljenosti prilikom izvršavanja odstrela krupne i sitne divljači. Pritom, procjena udaljenosti cilja, odnosno objekta koji se cilja vrlo je značajna za donošenje odluke o pucanju. Pravilna procjena veličine životinje, trofejne vrijednosti i kondicije obavlja se osmatranjem s veće ili manje udaljenosti, a često puta upravo taj segment predstavlja vrlo važan ekonomski čimbenik, koji u velikoj mjeri odražava dosadašnje gospodarenje i dirigira smjernice budućeg gospodarenja (Tomljanović i sur.,
2010). Lovačka populacija koja u Hrvatskoj čini 1,14\% ukupnog stanovništva (Pejnović i sur., 2010) različite je životne dobi, obrazovanja i lovačkog staža. Pri tome struktura lovaca s obzirom na životnu dob i obrazovanje je relativna nepoznanica, a još je veća nepoznanica u kojoj su mjeri pojedini segmenti praktičnog lovstva utjecani s lovačkim stažom, obrazovanjem ili starosti lovca. Kako bi se utvrdilo u kojoj mjeri dubinska percepcija ovisi o životnoj dobi ili iskustvu, stupnju obrazovanja, a potom i konfiguraciji terena i udaljenosti od cilja, provedeno je istraživanje procjene udaljenosti kod lovaca različite životne dobi, iskustva, obrazovanja, u različitim stanišnim uvijetima i udaljenostima od cilja.

\section{MATERIJALI I METODE MATERIAL AND METHODS}

U svrhu određivanja utjecaja konfiguracije terena, starosti, obrazovanja i lovačkog staža na procjenu udaljenosti, na uzorku od 40 lovaca provedeno je terensko ispitivanje. Lovci koji su sudjelovali u istraživanju procjenjivati su udaljenost deset nasumce odabranih objekata u prirodi. Kako bi se izbjegla pogreška zbog nepoznavanja objekta, procjenjivala se udaljenost dubećih stabala, panjeva, šumskih oznaka i sličnih objekata poznate veličine. Prema konfiguraciji terena istraživanje je podijeljeno na mjerenja koja su provedena u nizini (<200 m.n.v.), brdu (200 - 800 m.n.v.) i gorskom području (> 800 m.n.v.). Za svakog lovca još su bilježene godine starosti, lovački staž i stupanj obrazovanja. Radi lakše statističke obrade podaci o godinama starosti i lovačkom stažu grupirani su u kategorije raspona deset godina. U prikazu rezultata i analizi uspoređivale su se apsolutne vrijednosti pogrešnih procjena u odnosu na lovački staž, godine starosti, obrazovanje i lokalitet istraživanja.

Za svaku procjenu izvršeno je kontrolno mjerenje koje je provedeno laserskim daljinomjerom Extend LRS-1000, koji je opto-elektronički instrument, a koji funkcionira na način

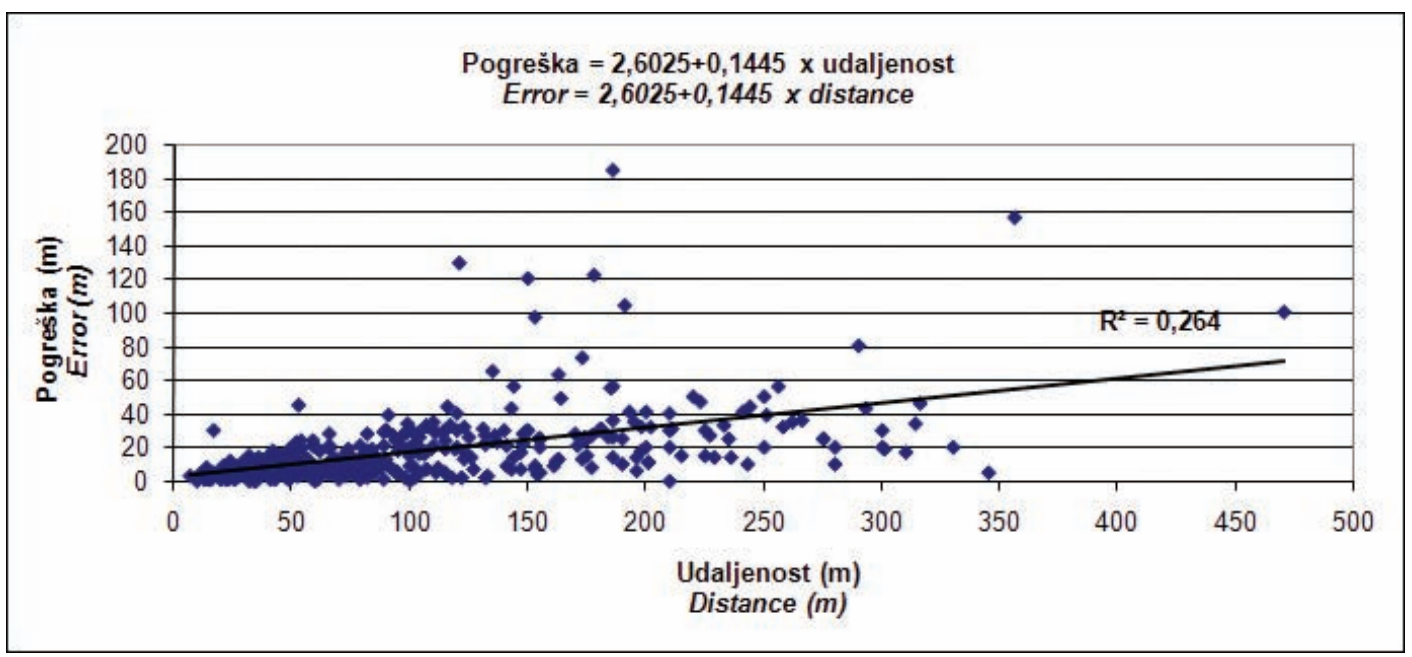

Slika 1. Prosječne pogreške procjena u odnosu na udaljenost. Figure 1. Average errors versus distance. 


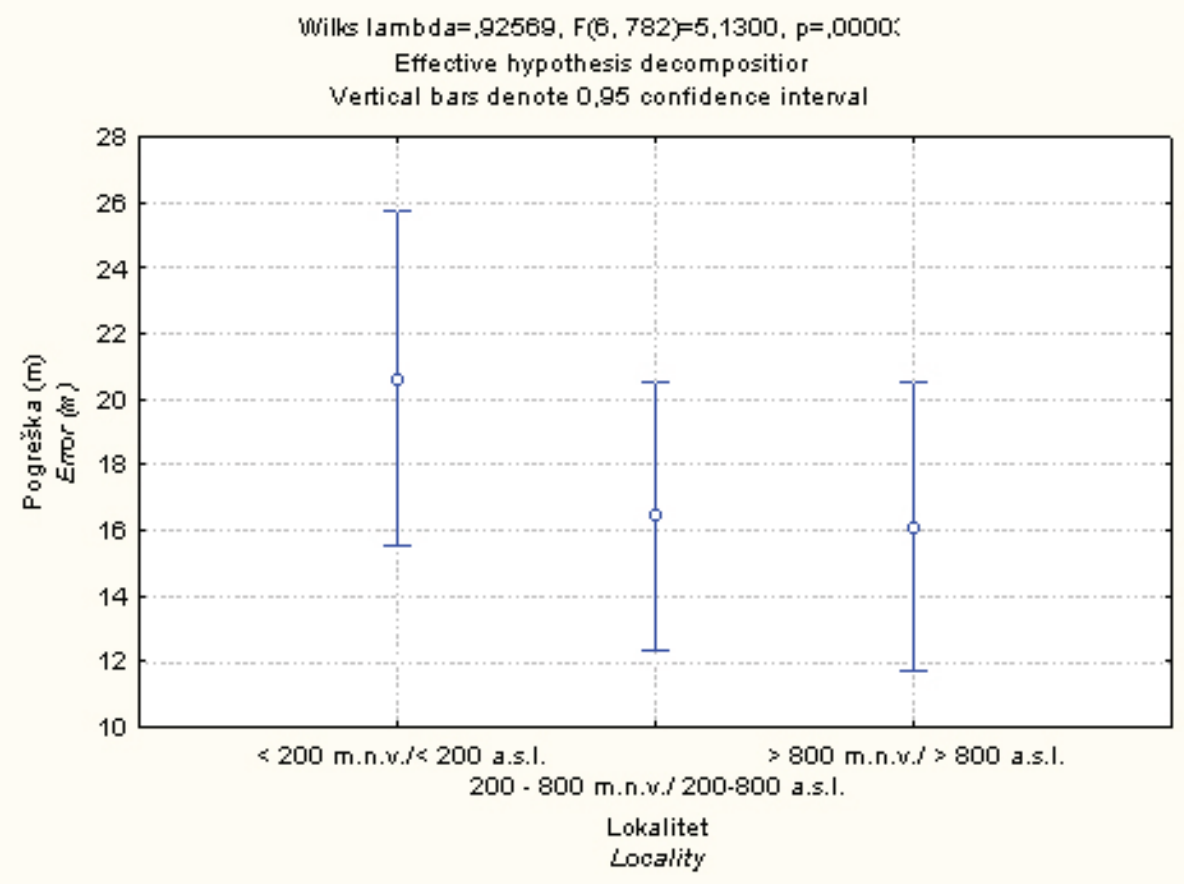

Slika 2. Apsolutna pogreška procjenjivane udaljenosti na različitim lokalitetima istraživanja.

Figure 2: The average error estimating distance from the various areas of research.

da laserska dioda emitira seriju nevidljivih IC pulseva koji se odbijaju od promatranog cilja natrag do instrumenta. Elektronički sklop izračunava udaljenost preračunavanjem vremena potrebnog svakom pulsu da se vrati do samog uređaja. Specificirano odstupanje uređaja od $+/-1 \%$ u rasponu mjerenja od $\min 5 \mathrm{~m}$ do $\max 1000 \mathrm{~m}$.

Tablična i statistička obrada podataka rađena je programima Statistica 8 i Excel.

\section{REZULTATI}

\section{RESULTS}

Tijekom istraživanja u eksperimentu je sudjelovalo ukupno 40 lovaca, uz čiju pomoć je provedeno sveukupno 400 procjena i kontrolnih mjerena. Od toga 110 procjena i kontrolnih mjerenja bilo je u nizinskom području, 180 procjena i kontrolnih mjerenja u brdskom području i 110 procjena i kontrolnih mjerenja u gorskom području. Od 40 lovaca njih 5 ima završenu osnovnu školu, 17 ih je srednje, 8 više, a 10 visoke stručne spreme. Prosječna starost sudionika istraživanja bila je 46 uz standardnu devijaciju od +/- 15,15 godina. Prosječan lovački staž sudionika iznosio je 16 godina uz sd +/- 10,7 god. Aritmetička sredina procjenjenih udaljenosti iznosila je 102,16m, dok je aritmetička sredina izmjerenih udaljenosti iznosila 104,82 m. Iako se aritmetička sredina svih pogrešaka ne čini prevelika, možda je relevantniji podatak o prosječnoj apsolutnoj pogrešci procjene koja iznosi $17,75 \mathrm{~m}$ uz sd +/- 20,62m ukupno ili gledano po područjima 20,60m uz sd +/- 27,09m za nizinsko područje, 16,93m uz sd +/- 19,46m za brdsko i 16,24 uz sd +/- 13,73m za gorsko područje.

Povećavanjem udaljenosti objekta čija se udaljenost procjenjuje, raste apsolutna pogreška, međutim smanjuje se relativna pogreška procjene. Na udaljenosti od $100 \mathrm{~m}$ prosječna pogreška svih procjena iznosi 17,5m ili 17,05\%, na udaljenosti od $150 \mathrm{~m}$ ta pogreška je $24,28 \mathrm{~m}$ ili $16,19 \%$, dok je na udaljenosti od 200m 31,5m ili 15,75\%.

Procjenjivane udaljenosti nalazile su se u rasponu od min. $7 \mathrm{~m}$ pa do max. $470 \mathrm{~m}$. Statističkom analizom utvrđene su razlike u pogreškama kod procjene između pojedinih područja istraživanja. Zanimljivo je da su prosječno manja odstupanja zabilježena u brdskom i gorskom području (>200 m.n.v.) dok su prosječno viša odstupanja zabilježena u nizinskom (<200 m.n.v.) području. Na sva tri područja istraživanja, aritmetička sredina procijenjenih udaljenosti bila je manja od sredine izmjerenih udaljenosti.

Analiza životne dobi pokazuje kako su prosječne pogreške najmanje u kategoriji 50 - 60 god., dok su najveće pogreške prosječno bilježene kod lovaca 60-70 god.

Kod analize lovačkog staža i njegovog utjecaja na procjenu udaljenosti ustanovljeno je da prosječno najmanje griješe lovci s lovačkim stažom 20-30 godina. Ono što je zanimljivo prosječno najveća pogreška u procjeni ustanovljena je kod lovaca s lovačkim stažom 10 - 20 god. Ujedno u toj kategoriji ustanovljeno je i najveće rasipanje odstupanja te je jedino ta kategorija lovaca prosječno procjenjivala veće udaljenosti od izmjerenih, za razliku od svih ostalih dobnih 


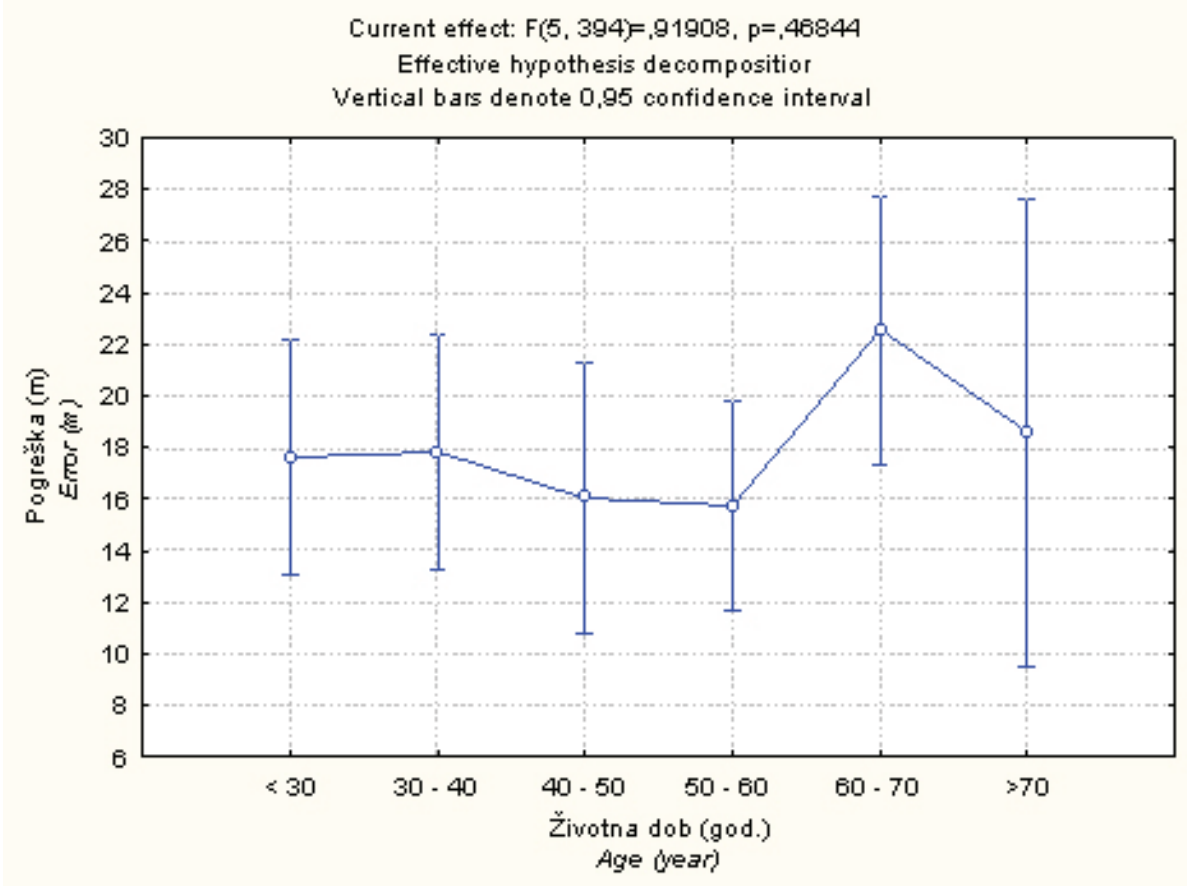

Slika 3. Pogreška procjenjivane udaljenosti u odnosu na životnu dob ispitanika.

Figure 3. A mistake estimation of distance in relation to the age of subjects.

kategorija koje su prosječno procjenjivale manju udaljenost od stvarno izmjerene.

Analizom utjecaja obrazovanja ustanovljeno je da su prosječno najmanje griješili lovci više naobrazbe, dok su najveće pogreške zabilježene kod lovaca srednje stručne spreme.
Korelacijskom analizom nije utvrđena značajna međusobna ovisnost ispitivanih parametara. Utvrđeno je da porastom životne dobi dolazi do određenih promjena u pogrešci procjene udaljenosti. Najmlađe ispitivane dobne kategorija, kao i najstarija, prosječno više giješe od onih u sredini.

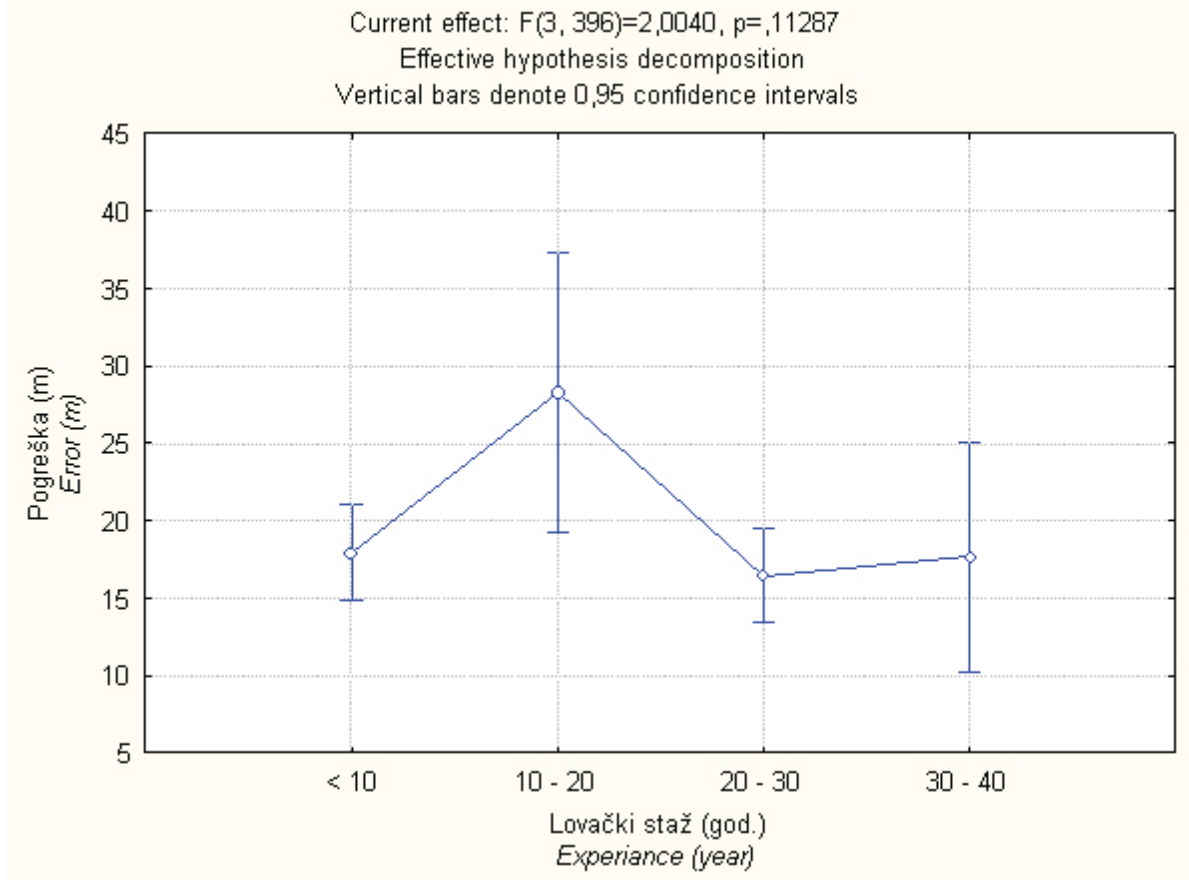

Slika 4. Prosječna pogreška procjenjivane udaljenosti u odnosu na lovački staž ispitanika Figure 4. A mistake estimation of distance in relation to hunting experience of subjects. 


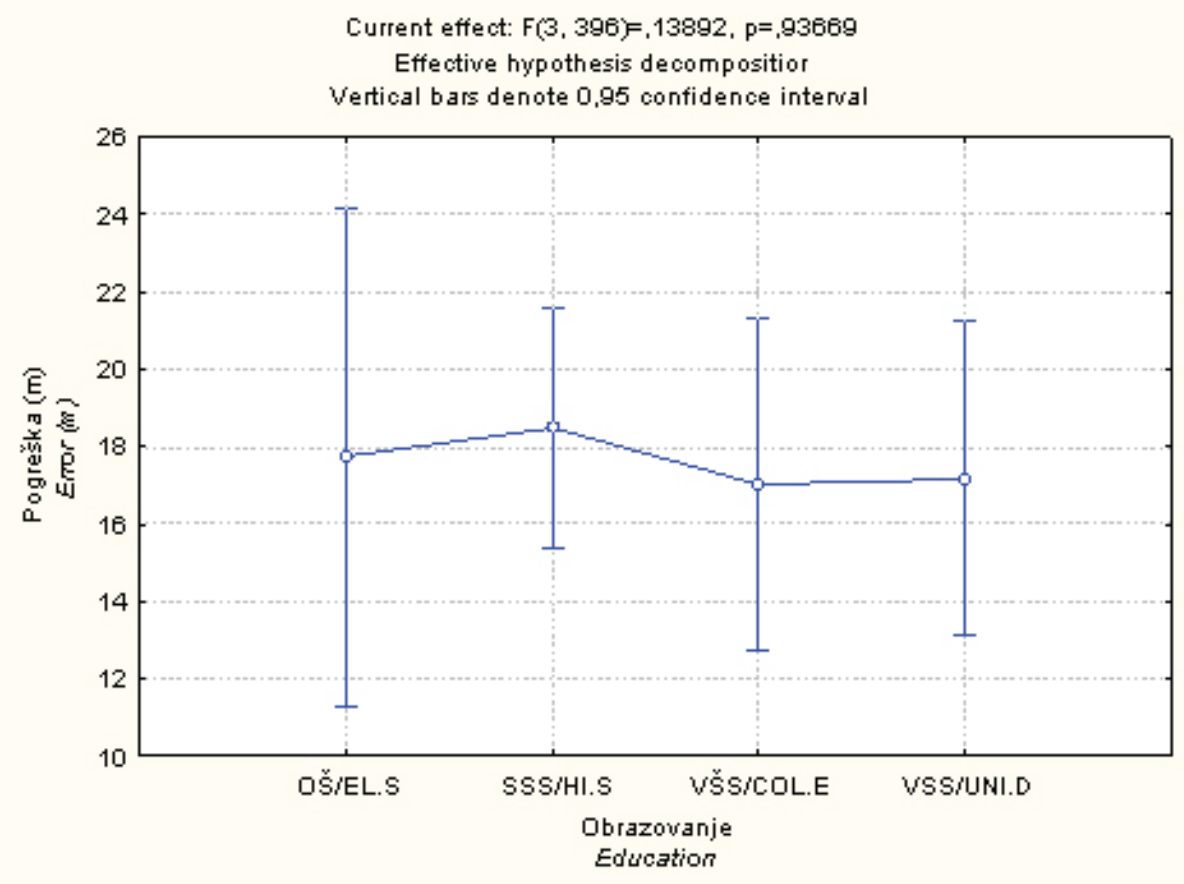

Slika 5. Prikaz prosječne pogreške procjenjivane udaljenosti u odnosu na stupanj obrazovanja ispitanika.

Figure 5. Average errors estimating distance from the level of educationof subjects.

\section{RASPRAVA I ZAKLJUČCI}

\section{DISSCUSION AND CONCLUSION}

Provedenim istraživanjem željelo se ponajprije utvrditi kako subjektivna procjena udaljenosti ovisi o različitim okolnostima. Očekivano, porastom udaljenosti objekta za koji se procjenjuje udaljenost, rasla je i apsolutna pogreška procjene te udaljenosti. Utvrđeno je da životna dob ima utjecaj na procjenu udaljenosti, odnosno pogrešku koja se kod procjene javlja. Kod najmlađih i najstarijih lovaca zabilježena je prosječno najveća pogreška, dok su najmanje pogreške zabilježene kod lovaca od 40 - 60 godina. Ovo donekle demantira istraživanja Bell i sur. (1972) koji su utvrdili da se vid pogoršava u četvrtoj dekadi života, a ide u prilog tezi da dubinska percepcija nije isključivo vezana uz starost (Hofstetter \& Bertsch 1976; Greene i Madden 1987; Yekta i sur 1989). U konkretnom istraživanju može se pretpostaviti da je pogreška kod najmlađe skupine lovaca rezultat nedovoljnog iskustva, dok je kod lovaca starijih od 60 god. to rezultat smanjene funkcionalnosti, što između ostaloga u svom istraživanju zaključuju i Norman i sur. (2000). Lovci stariji

\begin{tabular}{|c|c|c|c|c|c|c|}
\hline \multicolumn{7}{|c|}{ Marked correla tions are significant at $p<, 05000 \mathrm{~N}=400$} \\
\hline & $\begin{array}{l}\text { Procjena } \\
\text { A ssessnent }\end{array}$ & $\begin{array}{l}\text { Irmjer a } \\
\text { Measument }\end{array}$ & $\begin{array}{l}\text { Ods tu panje } \\
\text { Error }\end{array}$ & $\begin{array}{l}\text { Starost } \\
\text { Age }\end{array}$ & $\begin{array}{l}\text { Lov. Staí } \\
\text { Experiance }\end{array}$ & $\begin{array}{l}\text { Obrazovan je } \\
\text { Education }\end{array}$ \\
\hline \begin{tabular}{|l|} 
Procjena \\
Assessment
\end{tabular} & 1,00 & 0,93 & 0,16 & 0,05 & 0,04 & 0,18 \\
\hline \begin{tabular}{|l|} 
I mjera \\
Measurme nt
\end{tabular} & 0,93 & 1,00 & $-0,21$ & 0,05 & 0,05 & 0,20 \\
\hline $\begin{array}{l}\text { Odstup anje } \\
\text { Error }\end{array}$ & 0,16 & $-0,21$ & 1,00 & 0,00 & $-0,04$ & $-0,05$ \\
\hline $\begin{array}{l}\text { Starost } \\
\text { Age }\end{array}$ & 0,05 & 0,05 & 0,00 & 1,00 & 0,84 & $-0,21$ \\
\hline $\begin{array}{l}\text { Lov. Staì } \\
\text { Experiance }\end{array}$ & 0,04 & 0,05 & $-0,04$ & 0,84 & 1,00 & 0,02 \\
\hline $\begin{array}{l}\text { Obrazovanje } \\
\text { Educ afion }\end{array}$ & 0,18 & 0,20 & $-0,05$ & $-0,21$ & 0,02 & 1,00 \\
\hline
\end{tabular}

Tablica 1: Korelacijski faktori istraživanih parametara

Table 1: Correlation factorsof researchparameters 
od 70 godina pokazali su prosječno manju pogrešku od onih u kategoriji 60 - 70god., međutim s obzirom se radi o vrlo malom uzorku i rasipanje je puno veće, taj dio uzorka ne treba uzeti kao relevantan. Ako se promatra lovački staž, utvrđeno je da najviše griješe lovci s lovačkim stažom između 10 i 20 godina. Lovci koji se lovom bave kraće od deset godina prosječno su najmanje griješili, pa stoga ti rezultati opet idu u prilog tezi da je za procjenu udaljenosti manje bitno lovačko iskustvo te je presudna funkionalnost vida odnosno životna dob (Norman i sur., 2000). Zanimljivo je da su procjene udaljenosti provedene u brdskim predjelima (200 - 800 m.n.v.) gdje je konfiguracija terena brdovito brežuljkasta, kao i procjene u gorskom području (>800 m.n.v.) slična, te su u oba slučaja negativna. Ispitivanja provedena u nizinskim lovištima pokazuju kako lovci potcjenjuju udaljenost, međutim u prosjeku više griješe nego lovci ispitani u brdskom i gorskom području. Na neki način ovo je donekle i očekivan rezultat, jer u nizinskim predjelima teren je bez izraženog reljefa pa je i teže točno procjenjivati udaljenost objekata u prirodi. Analiza pogrešaka procjene u odnosu na stručnu spremu pokazala je da nema značajne međusobne ovisnosti, iako su prosječno griješili najmanje lovci sa završenom VŠS. dok su najveće pogreške zabilježene kod lovaca srednješkolskog obrazovanja.

\section{LITERATURA}

\section{REFERENCES}

- Abel, R., Oz, M. (2014): The Eye Care Revolution Prevent And Reverse Common Vision Problems, Revised And Updated Paperback.

- Bell, B., Wolf, E., Bernholz, C. D. (1972): Depth perception as a function of age. The International Journal of Aging and Human Development3(1), s. 77-81.

- Biederman, I., Mezzanotte, R. J., Rabinowitz, J. C. (1982): Scene perception: Detecting andjudging objects undergoing relational violations. Cognitive Psychology, 14(2), 143-177.

- Boyce, S. J., Pollatsek, A., Rayner, K. (1989): Effect of background information on objectidentification. Journal of Experimental Psychology: Human Perception and Performance, 15(3), s.556-566.

- Clare Thetford C., Bennett, K.M., Hodge, S. Knox, P. C., Robinson, J. (2015): Resilience and vision impairment in older people. Journal of Aging Studies 35, s. 37-48
- Gegenfurtner, K. R., Rieger, J. (2000): Sensory and cognitive contributions of color to therecognition of natural scenes. Current Biology, 10(13), 805-808.

- Greene, M.R. Oliva A. (2009): Recognition of natural scenes from global properties: Seeing the forest without representing the trees Cognitive Psychology, 58 (2) s. 137-179.

- Greene, H. A., Madden D. J. (1987): Adult age differences in visual acuity, stereopsis, andcontrastsensitivity. American Journal of Optometry \& Physiological Optics64, s. 749-753.

- Henderson, J. M., Hollingworth, A. (1999): High-level scene perception. Annual Review of Psychology, 50, s 243-271.

- Hofstetter, H., W., Bertsch J. D. (1976): Does stereopsis change with age?American Journal of Optometry \& Physiological Optics53, s. 664-667.

- Naoki Kogo, N., Anna Drożdżewska, A., Peter Zaenen, P., Nihan Alp, N., Johan Wagemans, J. (2014): Depth perception of illusory surfacesVision Research, 96, s. 53-64

- Norman, J. F., Dawson, T. E., Butler, A. K. (2000): The effects of age upon the perception of depth and 3-D shape from differential motion and binocular disparity. PERCEPTION- LONDON29(11), s. 1335-1360.

- Oliva, A., Schyns, P. (2000): Diagnostic colors mediate scene recognition.Cognitive Psychology, 41, s. 176-210.

- Pejnović, D., Krapinec, K., Slamar, M. (2010): Lovci u Hrvatskoj kao socijalno-geografska skupina i njihove demosocijalne karakteristike. Šumarski list, 134(9-10), 461-473.

- Rousselet, G. A., Joubert, O. R., Fabre-Thorpe, M. (2005): How long to get to the "gist" of real-world natural scenes?VisualCognition, 12(6), s. 852-877.

- Sanocki, T. (2003): Representation and perception of spatial layout.Cognitive Psychology, 47, s. 43-86.

- Sinha, D., Shukla, P. (1974): Deprivation and development of skill for pictorial depth perception. Journal of Cross-Cultural Psychology, 5(4), s. 434-450.

- Tomljanović, K., Grubešić, M., Krapinec, K. (2010): Testiranje primjenjivosti digitalnih senzornih kamera za praćenje divljači i ostalih životinjskih vrsta. Šumarski list, 134(5-6), 287-292.

- Tran, T. H. C., Rambaud, C., Despretz, P., Boucart, M. (2010): Scene perception inage-related macular degeneration. Invest Ophthalmol Vis Sci 51(12), s. 6868-6874.

- Yekta, A. A., Pickwell L. D., Jenkins T. C. A.(1989): Binocular vision, age and symptoms. Ophthalmology\& Physiological Optics9, s. $115-120$.

- Watson, M.R., Enns,J.T. (2012): Depth Perception in Encyclopedia of Human Behavior (Second Edition), Pages 690-696

\section{Summary}

Depth perception is the ability to see thre dimensional volume and special layout of objects in relation to one another as well as to the observer himself. This depth perception in humans is achieved by different signs in nature where the eyes or the brain relies on certain regularities in the environment (Watson \& Enss 2012). Knowing the size of the object from previous experience our brain can calculate distance based on the size of the object on the retina (Abel 2014). For proper depth perception it is necessary that both eyes focus the object synchronously. This way, observing the object simultaneously from two different angles a plastic image of the object is create in the brain (Tran and ass., 2010), and all other information on the observed object is 
being given (Greene \& Oliva 2009; Oliva \& Schyns 2000; Rousselet i sur., 2005; Sanocki 2003). In everyday hunting management proper assessment of distance of wild game, especially of big game species, is of crucial significance in executing cull. Most rifles that are now used for cull are equipped with optical sights that are generally calibrated at $100-150$ meters. Depending on the calibre, height of the optics, bullet weight, distance and angle from which you shoot, as well as some other less important parameters, depends the success of the cull itself and punctuality of the shot.Often is the case that the reason for missing in cull attempts should be looked for in the wrong assessment of distance of wild game. Distance assessment of objects in nature has been researched on the sample of 40 hunters of different age groups, hunting experience and education. Research has been conducted in three types of habitat, lowland (up to 200 a.s.l.), highland ( $200-800$ a.s.l.) and mountain (over 800 a.s.l.).To eliminate biases each hunter has been tested in ten differently distanced objects. Measurement control has been conducted with laser telemeter. Conducted research was supposed to determine that the bias distance assessment depends on different factors. As expected, by increasing the distance of the object for which distance was assessed, the distance assessment error also increased. It was determined that age has influence on distance assessment and assessment error that occurs. In youngest and oldest hunters the biggest average error has been noticed, while somewhat smaller errors have been noticed in hunters in the age group of 40 to 60 . It can be therefore assumed that the errors in the group of younger hunters is the result of insufficient experience, while in the group of hunters above 60 years of age this is the result of reduced functionality. Hunters that are older than 70 have shown on average smaller error than the ones in age category $60-70$ years of age, however considering that it is a small sample and dissipation is far bigger this part of the sample should not be considered relevant. This situation does not correspond to the errors that were noticed in analysing errors in correlation with hunting experience, especially when you take into account that hunting experience increases proportionally with age. Most errors were done by hunters with hunting experience between 10 and 20 years. Hunters that were hunting for less than ten years made less mistakes on average and therefore these results are also in favour of the thesis that for distance assesment hunting experience is less important, and that sight functionality and life age are crucial. Analysis of level of education show that the hunters with higher education made less errors. All hunters on average estimate smaller distance that the measured one. By increasing the distance the error in distance estimation is also increased.

KEY WORDS: estimation of distance, hunters, hunting management, habitat 
